\title{
Competition between the seagrasses Thalassia testudinum and Syringodium filiforme in a Caribbean lagoon*
}

\author{
Susan L. Williams** \\ West Indies Laboratory, Teague Bay, Christiansted, St. Croix, U.S. Virgin Islands 00820
}

\begin{abstract}
In typical Caribbean seagrass beds, several seagrass species co-occur and may compete for resources. The decline in Syringodium filiforme as Thalassia testudinum becomes abundant during successional development of Caribbean seagrass beds suggests that competition occurs between these seagrasses. The hypothesis that $T$. testudinum outcompetes $S$. filiforme for light and sediment nutrients was tested in situ within a shallow seagrass bed in St. Croix, U.S. Virgin Islands. Exploitative competition with $T$ testudinum for primarily sediment nutrients but also light limited the leaf shoot density of $S$. filiforme but had little effect on leaf growth. Removal of the $T$ testudinum leaf canopy increased light above the saturation level of photosynthesis by $S$. filiforme and leaf shoot density and belowground biomass of $S$. filiforme doubled within 9 mo compared to control areas. The T. testudinum canopy protected $S$. filiforme leaves from breaking. Fertilization of the sediments with nitrogen and phosphorus increased leaf shoot density and belowground biomass of $S$. filiforme, an effect enhanced by $T$. testudinum canopy removal. Belowground competition for nutrients limited the areal aboveground productivity of $S$. filiforme more than exploitation of light by $T$ testudimum. Increased shoot density of $S$. filiforme resulting from greater rhizome density, rhizome branching, and leaf pairs per node contributed more to enhanced aboveground productivity with additional light or nutrients than increases in leaf growth.
\end{abstract}

\section{INTRODUCTION}

Caribbean seagrass beds are commonly assemblages of green macroalgae of the order Caulerpales and the seagrass species Thalassia testudinum, Syningodium filiforme, and Halodule wrightii. During the successional development of Caribbean seagrass beds, $H$. wrightii and $S$. filiforme colonize bare sediments before T. testudinum (Den Hartog 1971, Patriquin 1975, Zieman 1976). Seagrass bed recolonization experiments on St. Croix, U.S. Virgin Islands indicate that densities of $S$. filiforme leaf shoots peak before $T$. testudinum becomes abundant and decline thereafter (Williams 1984, 1985). The decline in S. fillforme with increasing $T$. testudinum abundance suggests that $T$. testudinum interferes with the growth of $S$. filiforme. Interference is defined sensu Harper (1977) as a change in the environment created by the proximity of

\footnotetext{
- Contribution No. 162 from West Indies Laboratory

- Present address: Friday Harbor Labs, 620 University Rd,

Friday Harbor, Washington 98250, USA
}

individuals that 'may alter the growth rate or form' of neighboring individuals. 'Interference' does not specify mechanisms responsible for the changes, hence the major objective of my study was to elucidate those mechanisms.

One obvious change in the environment as Thalassia testudinum becomes increasingly dominant is the reduction of light under the canopy formed by $T$. testudinum leaves. $T$. testudinum has a much greater leaf area for interception of light than Syringodium filiforme. For example, a typical leaf width for $T$. testudinum is $1 \mathrm{~cm}$ in contrast to just over $1 \mathrm{~mm}$ for $S$. filiforme. Zieman et al. (1984) have shown that only 25 to $43 \%$ of the light impinging on the canopy penetrates to the substratum in 2 seagrass beds on St. Croix. The seagrasses Zostera marina and Heterozostera tasmanica respond to reduced light by decreasing leaf shoot density (Bachman \& Barilotti 1976, Dennison \& Alberte 1982, Bulthuis 1983). Photosynthesis of $S$. filiforme is presumably light-limited under a $T$. testudinum canopy. Earlier studies demonstrated that photosynthesis of $S$. filiforme reaches saturation at 
light levels $>50 \%$ of the irradiance reaching the surface of the water column (Williams \& McRoy 1982).

The primary objective of my study was to determine whether the leaf canopy of Thalassia testudinum interferes with Syringodium filiforme in terms of shoot density and leaf growth. The predicted effects of removing the $T$. testudinum canopy would be increases in shoot density and rates of leaf growth of $S$. filiforme. I tested this hypothesis in situ at the site of previous recolonization experiments. Another objective was to determine belowground interactions between the 2 seagrasses. Sediment nutrients limit seagrass growth in some seagrass beds but the limitation has never been tested in the Caribbean (Orth 1977, Bulthuis \& Woelkerling 1981, Short et al. 1985, Dennison et al. in press). I fertilized the sediments of the study seagrass bed to assess belowground competition between $T$. testudinum and $S$. filiforme for nutrients.

\section{METHODS}

The study site was a seagrass bed in $2 \mathrm{~m}$ of water in Tague Bay on the northeast coast of St. Croix, U.S. Virgin Islands at a site locally known as Romney Point $\left(17^{\circ} 45^{\prime} \mathrm{N}, 64^{\circ} 42^{\prime} \mathrm{W}\right)$.

Submarine photosynthetically active radiation (PAR) was measured with a LI-COR $1935 B 4 \pi$ sensor and a LICOR $188 \mathrm{~B}$ integrating quantum meter. At least 10 integrations of $10 \mathrm{~s}$ were taken from 1030 to $1200 \mathrm{~h}$ Atlantic Standard Time at each depth in October 1984 and December 1985.

Experimental manipulations of the seagrass bed are summarized in Table 1. In September 1984 I began clipping all Thalassia testudinum leaves at or just below the substratum every 7 to $10 \mathrm{~d}$ in eight $40 \times$ $40 \mathrm{~cm}$ plots. Four $40 \times 40 \mathrm{~cm}$ plots in the surrounding seagrass bed were unclipped controls ('controls'). Plots were selected haphazardly but treatments were assigned randomly to plots. In November 1984 in 4 of the original 8 clipped plots, I added clear plastic strips that mimicked the size and density of $T$, testudinum leaves in the surrounding bed to create a light-transmitting canopy (hereafter referred to as clipped \& plastic'). The plastic was tied to thin metal rods longer than the plot width and with $12 \mathrm{~cm}$ of each end bent at a right angle. The ends were gently pushed into the sediments outside the plot borders so that the rod rested just above the substratum. Care was taken to avoid bending $S$. filiforme leaves during placement. The plastic 'leaves' were replaced and $T$. testudinum was clipped every 7 to $10 \mathrm{~d}$.

In January 1985,8 new $40 \times 40 \mathrm{~cm}$ plots were established. Solid time-released fertilizer stakes (International Spike, Inc., Lexington, Kentucky, USA) were driven into the sediments of 4 newly clipped plots (hereafter referred to as 'clipped fertilized') and 4 new unclipped plots ('unclipped fertilized'). T. testudinum leaves were removed in the fertilized clipped plots every 7 to $10 \mathrm{~d}$. The fertilizer supplied a total of $35 \mathrm{~g} \mathrm{~N}$ and $8 \mathrm{~g} \mathrm{P}$ per $1 / 4 \mathrm{~m}^{2}$. An equivalent mass of the same fertilizer stimulated seagrass growth into cleared areas in previous experiments at this site (Williams unpubl. data). Half this amount of fertilizer was added again 11 mo later (see 'Results' for rationale).

Leaf shoot densities (hereafter referred to as shoot densities or densities) of Syringodium filiforme were counted in $1 / 16 \mathrm{~m}^{2}$ quadrats placed haphazardly in each of the 4 plots corresponding to a different manipulation (i.e. control, clipped, clipped \& plastic, clipped fertilized, unclipped fertilized). Quadrats were removed after counts were made. Two-way analysis of variance (ANOVA) was used to compare changes in densities of $S$. filiforme among experimental treatments and over time (Sokal \& Rohlf 1969). The assumptions of ANOVA were tested using Tukey's test for nonadditivity. If this test was significant, a data transformation was performed followed by another test of assumptions. Student-Newman-Keuls tests were used for multiple comparisons among means following significant ANOVA's. A $5 \%$ probability level $(p)$ was used unless otherwise stated. Fertilized control and clipped fertilized treatments were not compared to the clipped

Table 1. Experimental plan. Four plots per treatment. Thalassia testudinum canopy removal occurred every 7 to $10 \mathrm{~d}$

\begin{tabular}{|lll|}
\hline Plot & Initiation date & \multicolumn{1}{c}{ Treatment } \\
\hline Control & Sep 1984 & None \\
Clipped & Sep 1984 & Remove canopy \\
Plastic & & \\
Initially clipped & Sep 1984 & Remove canopy \\
Plastic added & Nov 1984 & Add plastic, continue canopy removal \\
Clipped fertilized & Jan 1985 & Remove canopy \\
Unclipped fertilized & Jan 1985 & Add $N+$ P to sediments \\
\end{tabular}


and clipped \& plastic treatments because of the 4 mo lag between initiation of the 2 experiments.

In 2 separate control and 2 separate fertilized plots, concentrations of ammonium and reactive phosphate were measured in sediment porewaters collected in diffusion chambers similar to those of Winfrey \& Zeikus (1977). Chambers were filled with $0.3 \mu \mathrm{m}$ glass fiber-filtered seawater which had been degassed with $\mathrm{N}_{2}$. A $0.2 \mu \mathrm{m}$ Nuclepore polycarbonate membrane was placed over sampling ports in the chamber and secured by a thin plexiglas faceplate. Immediately after fertilization, one chamber per plot was inserted in the sediments to a depth of up to $33 \mathrm{~cm}$. Two wk later the chambers were removed and kept cool and dark during immediate transport to the laboratory. Porewater processing followed methods in Williams et al. (1985).

Growth of Syringodium filiforme leaves was measured by marking a leaf near its base with a strip of aluminum tape $1.5 \mathrm{~mm}$ wide. At least 35 leaves were marked in each plot in each treatment. Temporary wire quadrats served as reference levels for taping and measuring. Leaf elongation was measured after $7 \mathrm{~d}$. Some leaves were not relocated and leaves and tags may have been lost, reducing the final sample size. Length increments were converted to dry weight using a regression between leaf length and dry weight after calcareous epiphytes were removed using $5 \% \mathrm{HCl}$ (sample size $n=100 ; r^{2}=0.89$ ). The sample included leaves of all sizes and ages. Small (less than $1 \mathrm{~mm}$ ) changes in leaf diameter are associated with $S$. filiforme leaves in this seagrass bed and such changes are positively associated with leaf age and frequently length. The regression thus calculates the dry weight of leaves of an average diameter. Because leaves from all 4 replicates of each treatment were pooled for a mean growth rate, the variance among samples within treatment replicates was lost (i.e. 'sacrificial pseudoreplication': Hulbert 1984). For this reason I did not use inferential statistics to test for differences in growth among treatments.

In February 1986, above and belowground biomass samples were collected from 0 to $30 \mathrm{~cm}$ sediment depth using a PVC corer (21 cm diameter). The depth interval included over $90 \%$ of the seagrass belowground biomass. A core was randomly selected and taken from each of 3 of the clipped, clipped fertilized, unclipped fertilized and control plots. Lengthy sample processing time restricted sample size. Sediment was washed from the samples and seagrass species were separated. Rhizome (long shoot) meristems, leaf shoots and rhizome branches (including those arising from branching of rhizome apices and from vegetative branching of short shoots, i.e. branch rhizomes or proliferation shoots) were counted, based on Tomlinson (1974). Total rhizome length was measured. Rhizome number was defined as the number of rhizome segments longer than $5 \mathrm{~cm}$, which may overestimate the actual number due to inadvertent breakage of rhizomes during sample processing. Rhizome number gives a relative measure of the numbers of individual long shoots in each core because presumably inadvertent breakage of rhizomes was equal among cores. All rhizome diameters and internode lengths were measured and averaged for each species in each core. Leaf biomass was separated from root and rhizome biomass at the base of the leaf sheath which was included in leaf biomass. All biomass was rinsed in freshwater, dried at $90^{\circ} \mathrm{C}$ and weighed.

Aboveground areal productivity of Syringodium filiforme was estimated because it is a parameter commonly used to compare seagrass growth (McRoy \& McMillan 1977, Zieman \& Wetzel 1980) and it combines measures of leaf growth and shoot density. Mean leaf growth rates and the range in density counts from December 1985 were used. Leaf growth rates were multiplied by 2 leaves per shoot and converted to dry weight using the empirically-derived regression.

All data were converted to a $\mathrm{m}^{2}$ basis for ease of comparison with other seagrass studies.

\section{RESULTS}

\section{Canopy removal}

Light reaching the top of the Thalassia testudinum canopy was approximately $70 \%$ of irradiance at the top of the water column. Light levels at the base of the canopy were reduced to $33 \%$ of surface values (Fig. 1).
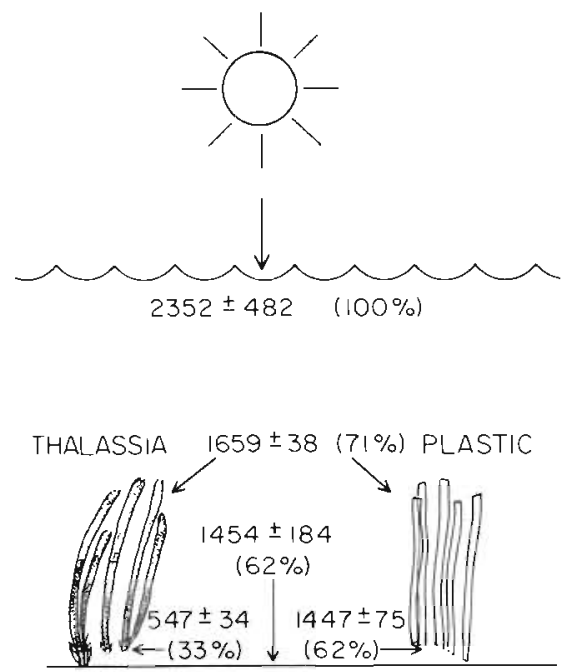

Fig. 1. Light transmittance through a canopy of Thalassia testudinum leaves, transparent leaves, and no canopy. Mean $\mu$ Ein $\mathrm{m}^{-2} \mathrm{~s}^{-1} \pm 1$ standard deviation 
Irradiance at midday within the canopy was therefore below the $50 \%$ level necessary to saturate photosynthesis of Syringodium filiforme (Williams \& McRoy 1982). Removal of the $T$. testudinum canopy increased the light passing through a canopy of $S$. filliforme leaves and rhizophytic algae to $>50 \%$.

Density of Syringodium filiforme increased significantly in the plastic plots 9 mo after plastic was added (2-way ANOVA, $p<0.01$; Fig. 2). Thereafter, all treatments were significantly different from controls.

Syringodium filliforme leaf growth did not appear to increase with increased light following canopy removal (Table 2). Within 1 wk after canopy removal, $S$. filiforme leaves were shorter than under the Thalassia testudinum canopy (Fig. 3). The plastic canopy did not noticeably affect the growth rate of $S$. filiforme leaves but leaves were longer under it (Fig. 3). The plastic canopy transmitted light well (Fig. 1). S. fillforme leaves rarely grew above the top of the plastic or the $T$. testudinum canopy in the control areas (Fig. 3). S. filiforme density was eventually highest under the plastic canopy (Fig. 2). These data suggest that the $T$. testudinum canopy plays a role in protecting $S$. filiforme leaves from breakage caused by water motion or the background level of grazing activity present, which may enable increased leaf shoot density.

\section{Fertilization}

Dissolution of the fertilizer during the first $2 \mathrm{wk}$ following application raised porewater ammonium concentrations by 2 orders of magnitude and phos-

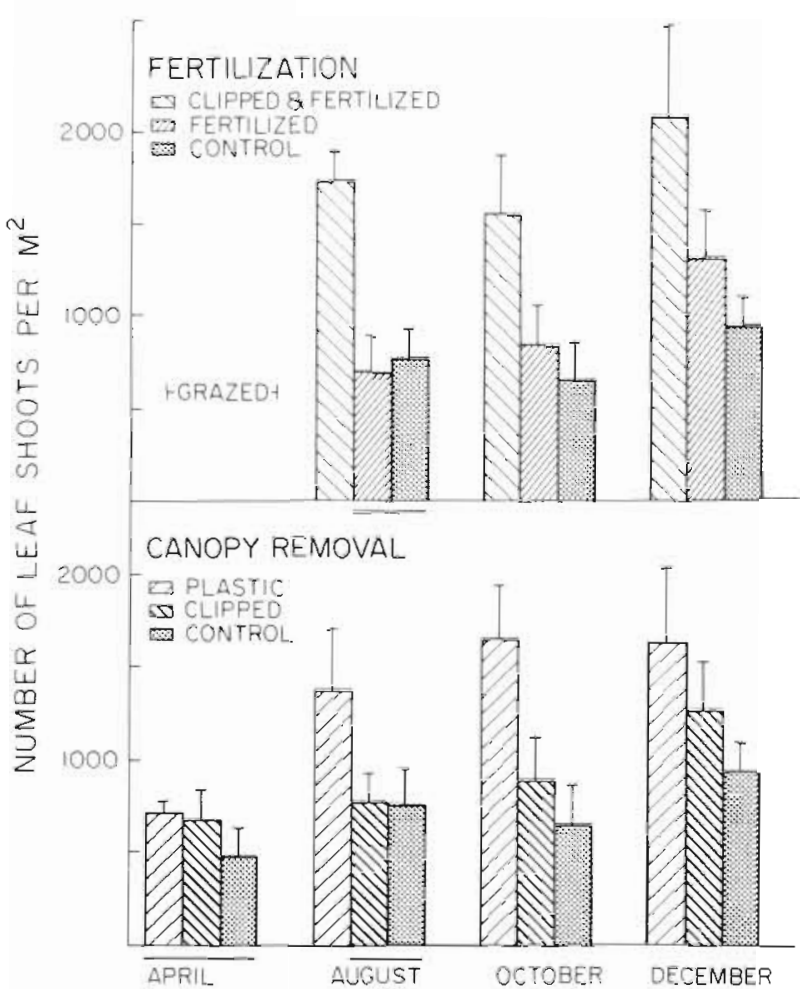

Fig. 2. Syningodium fillorme. Leaf shoot density during 1985 after removal of the Thalassia testudinum leaf canopy (lower half of graph) in Sep 1984 and fertilization of sediments (upper half of graph) in Jan 1985. 'Clipped' refers to removal of the $T$ testudinum canopy, 'plastic' to replacement of the $T$. testudinum canopy with clear plastic strips, 'control' to the natural seagrass bed (unclipped, unfertilized). Mean values from four $1 / 16 \mathrm{~m}^{2}$ plots +1 standard deviation (vertical error bar). Lines under vertical bars indicate groups of means not significantly different at $p<0.05$

Table 2. Syringodium filiforme. Leaf elongation rates ( $\mathrm{mm}$ leaf $\mathrm{f}^{-1} \mathrm{~d}^{-1}$ ). Values are $\overline{\mathrm{x}} \pm 1$ standard deviation (sample size). Dash no data. Control: leaves within a Thalassia testudinum canopy

\begin{tabular}{|c|c|c|c|c|c|}
\hline \multicolumn{6}{|c|}{ Type of plot } \\
\hline Date & Clipped & Clipped \& plastic & Control & $\begin{array}{l}\text { Unclipped } \\
\text { fertilized }\end{array}$ & $\begin{array}{l}\text { Clipped \& } \\
\text { fertilized }\end{array}$ \\
\hline $10 \mathrm{Sep} 84$ & $5.3 \pm 4.0$ & - & $6.3 \pm 4.0$ & - & - \\
\hline $14 \mathrm{Sep} 84$ & $4.9 \pm 2.1(45)$ & - & $7.5 \pm 3.8(40)$ & - & - \\
\hline 21 Sep 84 & $4.2 \pm 2.1(32)$ & - & $5.0 \pm 2.5(36)$ & - & - \\
\hline $28 \operatorname{Sep} 84$ & $5.0 \pm 1.7(34)$ & - & $5.7 \pm 2.7(33)$ & - & - \\
\hline 5 Oct 84 & $4.8 \pm 2.2(35)$ & - & $5.5 \pm 2.6(37)$ & - & - \\
\hline 12 Oct 84 & $4.7 \pm 2.2\{22\}$ & - & $5.9 \pm 2.9(35)$ & - & - \\
\hline 19 Oct 84 & $4.8 \pm 2.2(28)$ & - & $5.4 \pm 2.7(36)$ & - & - \\
\hline 26 Oct 84 & $4.6 \pm 2.0(26)$ & - & $5.8 \pm 2.6$ & - & - \\
\hline 10 Nov 84 & $4.1 \pm 1.4(10)$ & - & $5.1 \pm 2.1(21)$ & - & - \\
\hline $24 \operatorname{Jan} 85$ & $3.2 \pm 1.3(28)$ & $3.8 \pm 1.5(27)$ & $3.9 \pm 1.7(23)$ & $4.4 \pm 2.9(14)$ & $5.0 \pm 2.4(26)$ \\
\hline $31 \operatorname{Jan} 85$ & $3.4 \pm 1.6(26)$ & $3.3 \pm 1.2(33)$ & $4.0 \pm 1.9(38)$ & $5.9 \pm 2.4(5)$ & $-\cdot$ \\
\hline 17 Jun 85 & $4.0 \pm 1.3(31)$ & $4.2 \pm 1.8(34)$ & $4.0 \pm 1.4(24)$ & $4.9 \pm 1.9(15)$ & $5.2 \pm 1.6(24)$ \\
\hline 3 Jul 85 & $5.2 \pm 1.8(32)$ & $4.3 \pm 1.6(19)$ & $4.7 \pm 2.3(25)$ & $6.0 \pm 1.9\{21]$ & $5.8 \pm 1.6(23)$ \\
\hline $27 \mathrm{Dec} 85$ & $8.4 \pm 1.4(32)$ & $7.0 \pm 2.1(30)$ & $8.5 \pm 1.7(34)$ & $10.6 \pm 1.9$ & $9.8 \pm 1.0(11)$ \\
\hline
\end{tabular}




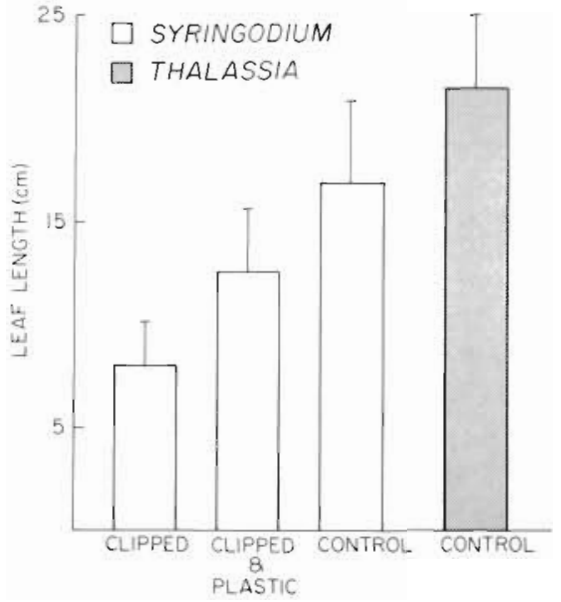

Fig. 3. Syringodium filiforme and Thalassia testudinum $(\mathrm{n}=$ 30). Mean leaf lengths +1 standard deviation (vertical error bar). 'Clipped' refers to removal of the $T$. testudinum leat canopy, 'clipped \& plastic' to replacement of the $T$. testudinum canopy with clear plastic strips, 'control' to the unclipped canopy

phorus concentrations 1 order of magnitude above the concentrations in the control seagrass bed (Table 3 ). Concentrations should have been highest just after fertilization but have remained above control levels for a minimum of 6 mo, based on results from my unpublished studies. After $2 \mathrm{mo}$, the tops of the fertilizer spikes were still visible just below the sediment surface but had decreased in bulk.

Fertilization of the sediments had dramatic effects on the seagrass bed and resident foraging animals. A week after application of the fertilizer, virtually all seagrass leaves in both clipped fertilized and unclipped fertilized plots were grazed to the substratum primarily by juvenile scarid parrotfishes. Leaves were broken possibly by the activities of goatfishes and black-eared wrasses. Fertilization resulted in a bloom of seagrass epiphytes, primarily filamentous red and some green algae but also larger species such as Hypnea sp. and Dictyota sp. The catastrophic grazing effect was apparently related to the algal bloom or other indirect effect of the fertilizer rather than a direct one, e.g. a chemical cue leaching from the fertilizer, because no enhanced grazing occurred when I placed fertilizer spikes on stakes elevated $30 \mathrm{~cm}$ above the canopy. These stakes decreased in size over $4 \mathrm{wk}$, indicating solubilization of the fertilizer. Recovery of seagrass leaf biomass was apparent $6 \mathrm{wk}$ after fertilization but was not complete until $10 \mathrm{wk}$ had elapsed.

Fertilization increased Syringodium filiforme leaf growth indicating nutrient limitation in the natural seagrass bed (Table 2). Nutrient limitation may provide a partial explanation for the lack of any noticeable increase in growth in the unfertilized areas after canopy removal. Fertilizer was added to the clipped fertilized and unclipped fertilized plots in December 1985 because I judged that the initial difference between leaf growth of fertilized versus unfertilized $S$. filiforme was decreasing, indicating depletion of fertilizer. I added only half the original amount to avoid catastrophic grazing. Catastrophic grazing did occur but was less severe.

A 2-way ANOVA indicated that changes in the density of Syringodium filiforme were significant over time $(p<0.025)$ and among unclipped fertilized, clipped fertilized, and control areas $(p<0.01)$ (Fig. 2). The density of $S$. filiforme doubled 4 mo after initial fertilization. Densities in fertilized areas increased faster and reached greater numbers when the Thalassia testudinum canopy was removed.

Table 3. Concentration of ammonium and reactive phosphorus dissolved in sediment porewaters of control and unclipped fertilized plots. Values are means from 2 plots \pm 1 standard deviation. Dash: no data due to broken membranes over sampling ports of diffusion chambers

\begin{tabular}{|ccccc|}
\hline & \multicolumn{2}{c|}{ Ammonium $(\mu \mathrm{M})$} & \multicolumn{2}{c|}{$\begin{array}{c}\text { Phosphorus }(\mu \mathrm{M}) \\
\text { Unclipped fertilized }\end{array}$} \\
\hline Sediment depth $(\mathrm{cm})$ & Control & Unclipped fertilized & Control & $0.45 \pm 0.53$ \\
$-1-1$ & $3.22 \pm 3.22$ & $74 \pm 96$ & $0 \pm 0$ & 2.79 \\
$-5-7$ & $5.80 \pm 1.96$ & 1214 & $0.04 \pm 0.05$ & 4.76 \\
$-8-10$ & $4.86 \pm 0.96$ & $1710 \pm 1820$ & $0.14 \pm 0.19$ & 6.12 \\
$-11-13$ & $26.0 \pm 28.7$ & 3800 & - & $64 \pm 85$ \\
$-14-16$ & 19.7 & $2840 \pm 1330$ & - & 120 \\
$-17-19$ & - & 2971 & - & $67 \pm 93$ \\
$-20-22$ & - & $1770 \pm 993$ & - & 0.41 \\
$-23-25$ & - & 1230 & 0.20 & 1.36 \\
$-26-28$ & 38 & 2140 & 0.27 & 1.50 \\
$-29-31$ & 58 & 2110 & & 0.95 \\
\hline
\end{tabular}




\section{Biomass allocation}

Although variance was high within samples from a treatment, changes in seagrass morphology and biomass were obvious upon visual inspection of the cores. The following description of these changes helps to explain how the increases in Syringodium filiforme density were effected following clipping of Thalassia testudinum or fertilization.

Seagrasses have several morphological alternatives for increasing leaf shoot density. The increased shoot density of Syringodium filiforme following removal of the Thalassia testudinum canopy or fertilization resulted from: (1) an increased number of individual rhizomes per unit area; (2) increased branching of individual rhizomes; and (3) an increased number of multiple leaf pairs per node (nodes typically have a single leaf pair) (Table 4). These increases indicate stimulation of lateral (short shoot) meristems. Internode lengths remained largely unchanged from the control plants, indicating that the rhizome growth rate may have increased.

Canopy removal or fertilization resulted in increased above and belowground biomass of Syringodium filiforme. Aboveground biomass increased proportionately more than belowground biomass. The increase in leaf shoot density compensated for the loss of biomass through breakage of leaves in the clipped plots; leaf biomass in clipped plots was greater than in control plots.

Thalassia testudinum morphology and biomass changed following leaf removal but not fertilization (Table 4). Weekly removal of leaves caused a significant reduction in belowground biomass and many shells of senescent rhizomes were found in the cores.

\section{Syringodium filiforme aboveground productivity: effects of competition with Thalassia testudinum}

Areal aboveground productivity is an integrative measure of 2 components of plant fitness: leaf growth and shoot density. Areal aboveground productivity data indicate that: (1) belowground competition with Thalassia testudinum for nutrients was more important than light; and (2) the effect of competition on Syrin-

Table 4. Syringodium filiforme and Thalassia testudinum. Effects of canopy removal and fertilization on seagrass morphology and biomass allocation. Values represent mean \pm standard deviation per $\mathrm{m}^{2}, \mathrm{n}=3$. Cores taken Feb 1986

\begin{tabular}{|c|c|c|c|c|c|c|c|c|}
\hline \multirow[t]{2}{*}{ Type of plot } & \multicolumn{4}{|c|}{ Syringodium filiforme } & \multicolumn{4}{|c|}{ Thalassia testudinum } \\
\hline & Clipped & Control & $\begin{array}{l}\text { Unclipped } \\
\text { fertilizer }\end{array}$ & $\begin{array}{l}\text { Clipped \& } \\
\text { fertilizer }\end{array}$ & Clupped & Control & $\begin{array}{l}\text { Unclipped } \\
\text { fertilizer }\end{array}$ & $\begin{array}{l}\text { Clipped \& } \\
\text { fertilizer }\end{array}$ \\
\hline $\begin{array}{l}\text { Total rhizome length } \\
\text { (cm) }\end{array}$ & $5469 \pm 886$ & $2768 \pm 2371$ & $4377 \pm 741$ & $5022 \pm 1064$ & $5083 \pm 3402$ & $11873 \pm 1328$ & $11725 \pm 1328$ & $5081 \pm 1414$ \\
\hline Rhizome number & $463 \pm 49$ & $251 \pm 188$ & $405 \pm 0$ & $521 \pm 153$ & $414 \pm 148$ & $967 \pm 157$ & $1002 \pm 509$ & $385 \pm 73$ \\
\hline Rhizome branches & $193 \pm 88$ & $19 \pm 33$ & $174 \pm 76$ & $48 \pm 83$ & $10 \pm 17$ & $39 \pm 44$ & $97 \pm 35$ & $39 \pm 67$ \\
\hline $\begin{array}{l}\text { Mean internode length } \\
(\mathrm{mm})\end{array}$ & $15.1 \pm 0.5$ & $16.0 \pm 0.7$ & $15.4 \pm 1.9$ & $17.2 \pm 2.3$ & $39.4 \pm 3.0$ & $43.0 \pm 3.8$ & $44.9 \pm 1.9$ & $47.0 \pm 0.5$ \\
\hline $\begin{array}{l}\text { Mean rhizome } \\
\text { diameter (mm) }\end{array}$ & $2.6 \pm 0.3$ & $2.7 \pm 0.1$ & $2.4 \pm 0.1$ & $2.4 \pm 0.1$ & $4.7 \pm 0.7$ & $4.5 \pm 0.4$ & $4.2 \pm 0.1$ & $4.4 \pm 0.1$ \\
\hline Rhizome meristems & $193 \pm 44$ & $19 \pm 17$ & $173 \pm 100$ & $222 \pm 133$ & $87 \pm 126$ & $299 \pm 89$ & $270 \pm 159$ & $87 \pm 29$ \\
\hline Leaf shoots & $2495 \pm 73$ & $1021 \pm 2371$ & $2071 \pm 590$ & $2312 \pm 827$ & $462 \pm 356$ & $1.667 \pm 535$ & $1137 \pm 392$ & $482 \pm 136$ \\
\hline Multiple shoots" & $183 \pm 83$ & $68 \pm 35$ & $154 \pm 88$ & $116 \pm 76$ & $0 \pm 0$ & $0 \pm 0$ & $0 \pm 0$ & $0 \pm 0$ \\
\hline Leaves ( $g$ dry) & $34.2 \pm 7.8$ & $24.5 \pm 24.2$ & $50.1 \pm 19.3$ & $25.9 \pm 3.8$ & $14.6 \pm 15.7$ & $207 \pm 52$ & $134 \pm 53$ & $11.9 \pm 7.2$ \\
\hline $\begin{array}{l}\text { Rhizomes \& roots } \\
\qquad \text { (g dry) }\end{array}$ & $99.1 \pm 27.0$ & $57.7 \pm 46.2$ & $62.1 \pm 5.7$ & $61.1 \pm 4.6$ & $412 \pm 335$ & $1092 \pm 209$ & $774 \pm 395$ & $269 \pm 41$ \\
\hline $\begin{array}{l}\text { Aboveground/below- } \\
\text { ground ( } \mathrm{g} d r y)\end{array}$ & $0.37 \pm 0.19$ & $0.30 \pm 0.16$ & $0.81 \pm 0.28$ & $0.45 \pm 0.08$ & $0.06 \pm 0.07$ & $0.19 \pm 0.03$ & $0.19 \pm 0.08$ & $0.05 \pm 0.03$ \\
\hline
\end{tabular}

Table 5. Syringodium filiforme. Comparison of effects of Thalassia testudinum canopy removal versus fertilization of sediments on aboveground productivity, 1985. Values are means or range

\begin{tabular}{|c|c|c|c|c|}
\hline Parameter & $\begin{array}{l}\text { + Canopy } \\
\text { - Fertilizer }\end{array}$ & $\begin{array}{l}\text { - Canopy } \\
\text { - Fertilizer }\end{array}$ & $\begin{array}{l}\text { + Canopy } \\
\text { - Fertilizer }\end{array}$ & $\begin{array}{l}\text { - Canopy } \\
\text { + Fertilizer }\end{array}$ \\
\hline Leaf shoot productivity ( $\mathrm{mg}$ dry wt $\mathrm{d}^{-1}$ ) & 1.4 & 1.3 & 1.6 & 1.7 \\
\hline Shoot density $\left(\# \mathrm{~m}^{-1}\right)$ & $816-1184$ & $929-1552$ & $1072-1648$ & $1728-2768$ \\
\hline Productivity (g dry wt $\mathrm{m}^{-2} \mathrm{~d}^{-1}$ ) & $1.14-1.66$ & $1.21-2.02$ & $1.72-2.64$ & $2.94-4.71$ \\
\hline
\end{tabular}


godium filiforme was mediated primarily through changes in shoot density rather than leaf growth (Table 5). Fertilization plus canopy removal resulted in a nearly 3 -fold increase in $S$. filiforme aboveground productivity.

\section{DISCUSSION}

The majority of examples of competition among marine plants occur in the rocky intertidal environment (Lubchenko \& Menge 1978, Sousa et al. 1981, Dayton et al. 1984, Dethier 1984, Paine 1984, Turner 1985). Competition among plants in the rocky intertidal is typically categorized as 'interference' competition sensu Miller (1967), where a dominant plant limits access by another to a resource: frequently space. The specific mechanisms responsible for pre-emption of space remain largely undetermined. A few studies on laboratory cultures of mixed species of macroalgae growing under various light-temperature gradients have provided information on the 'exploitation' component of competition (Miller 1967), i.e. resulting from collective access to a resource (Russell \& Fielding 1974, Enright 1979). Results of laboratory studies, while aiding selection of hypothetical mechanisms, do not necessarily predict competitive outcomes in the field where other factors such as herbivory and physical forces combine with potential competitive relationships to structure a particular plant community.

Competition among seagrasses or seagrasses and macroalgae has been mostly inferred (Patriquin 1972, Young \& Kirkman 1975, Harrison 1979, Birch \& Birch 1984, Pulich 1985). However, Turner (1985) experimentally demonstrated that the surfgrass Phyllospadix scouleri pre-empts space from various algae in the rocky intertidal, a form of interference competition. My study indicates that the decline in Syringodium filiforme shoot density as Thalassia testudinum becomes dominant during temporal development of a Caribbean seagrass bed is a result of exploitative competition primarily for sediment nutrients but also light.

The result of removing the Thalassia testudinum canopy is an increase in irradiance above the saturation level of Syringodium filiforme photosynthesis, based on the photosynthesis-irradiance curves of Williams \& McRoy (1982). Indirect evidence for increased photosynthesis following canopy removal is derived from the increases observed in $S$. filiforme biomass in the clipped plots rather than changes in leaf growth. A pattern for resource allocation in S. filiforme is evident from fertilization experiment results (Tables $2 \& 4$ ). Increases in either light or nutrients results in increased biomass with more devoted to the aboveground component.
In nature, environmental factors that are not essential for growth can mediate the results of competition between organisms for limited resources. The Thalassia testudinum canopy reduces light to levels limiting to Syringodium filiforme photosynthesis but protects $S$. filiforme leaves from breaking. Short, broken leaves were associated with decreased shoot density, perhaps reflecting a cost in terms of reduced photosynthetic area or increased respiration after wounding. I could not separate the effects of increased water motion or exposure to herbivory on rates of leaf breakage following removal of the $T$. testudinum canopy.

Acknowledgements. This research benefited from the comments of Drs. William Dennison, Valrie Gerard, and John Ogden. Meg Andronaco, Bruce Nyden, Ellen Praeger, and Eric Telemaque assisted with light measurements, clipping, and coring. Drs. Robert Carpenter and William Dennison made invaluable comments on the manuscript. I appreciated the comments of anonymous reviewers; a particularly thorough one was very helpful.

\section{LITERATURE CITED}

Bachman, T. W. Barilotti, D. C. (1976). Irradiance reduction: effects on standing crops of the eelgrass Zostera marina in a coastal zone. Mar Biol. 34: 33-40

Birch, W. R., Birch, M. (1984). Succession and pattern of tropical intertidal seagrass in Cockle Bay, Queensland, Australia: a decade of observations. Aquat. Bot. 19: 343-367

Bulthuis, D. A., Woelkerling, W. J. (1981). Effects of in situ nitrogen and phosphorus enrichment of the sediments on the seagrass Heterozostera tasmanica in Western Port, Victoria, Australia. J. exp. mar. Biol. Ecol. 53: 193-207

Bulthuis, D. A. (1983). Effects of in situ light reduction on density and growth of the seagrass Heterozostera tasmanica (Martens ex Aschers.) den Hartog in Western Port, Victoria, Australia. J. exp. mar. Biol. Ecol. 67: 91-103

Dayton, P. K., Currie, V., Gerrodette, T., Keller, B. D., Rosenthal, R., Ven Tresca, D. (1984). Patch dynamics and stability of some California kelp communities. Ecol. Monogr. 54: $253-289$

Den Hartog, C. (1971). The dynamic aspect in the ecology of sea-grass communities. Thalassia jugosl. 7: 101-112

Dennison, W. C., Alberte, R. S. (1982). Photosynthetic responses of Zostera marina L. (eelgrass) to in situ manipulations of light intensity. Oecologia (Berl.) 55: 137-144

Dennison, W. C., Aller, R. C., Alberte, R. S. Influence of sediment ammonium on Zostera marina (eelgrass) growth. Mar. Biol. (in press)

Dethier, M. N. (1984). Disturbance and recovery in intertidal pools: maintenance of mosaic patterns. Ecol. Monogr. 54: 99-118

Enright, C. T (1979). Competitive interaction between Chondrus crispus (Florideophyceae) and Ulva latuca (Chlorophyceae) in Chondrus aquaculture. Proc. Int. Seaweed Symp. 9: 209-218

Harper, J. L. (1977). Population biology of plants. Academic Press, London

Harrison, P. G. (1979). Reproductive strategies intertidal 
populations of two co-occurring seagrasses (Zostera spp.). Can. J. Bot. 57: 2635-2638

Hulbert, S. H. (1984). Pseudoreplication and the design of ecological field experiments. Ecol. Monogr. 54: 187-211

Lubchenko, J., Menge, B. A. (1978). Community development and persistence in a low rocky intertidal zone. Ecol. Monogr. 59: 67-94

McRoy, C. P., McMillan, C. (1977). Productivity and physiological ecology of seagrasses. In: McRoy, C. P., Helfferich, C. (ed.) Seagrass ecosystems: a scientific perspective. M. Dekker, New York, p. 53-88

Miller, R. S. (1967). Pattern and process in competition. Adv ecol. Res. 4: 1-74

Orth, R. J. (1977). Effect of nutrient enrichment on growth of the eelgrass Zostera marina in the Chesapeake Bay, Virginia, U.S.A. Mar. Biol. 44: 187-194

Paine, R. T. (1984). Ecological determinism in the competition for space. Ecology 65: 1339-1348

Patriquin, D. G. (1972). Origin of nitrogen and phosphorus for growth of the marine angiosperm Thalassia testudinum. Mar. Biol. 15: 35-46

Patriquin, D. G. (1975). 'Migration' of blowouts in seagrass beds at Barbados and Carriacou, West Indies, and its ecological and geological implications. Aquat. Bot. 1: 163-189

Pulich, W., Jr. (1985). Seasonal growth dynamics of Ruppia maritima Aschers in southern Texas and evaluation of sediment fertility types. Aquat. Bot. 23: 53-66

Russell, G., Fielding, A. H. (1974). The competitive properties of marine algae in culture. J. Ecol. 62: 689-698

Short, F. T., Davis, M. W., Gibson, R. A., Zimmerman, C. F. (1985). Evidence for phosphorus limitation in carbonate sediments of the seagrass Syringodium filiforme. Estuar. coast. Shelf Sci. 20:419-430

Sokal, R. R., Rohlf, F. (1969). Biometry. W. H. Freeman and Co., San Francisco
Sousa, W. P., Schroeter, S. C., Gaines, S. D. (1981). Latitudinal variation in intertidal algal community structure: the influence of grazing and vegetation propagation. Oecologia (Berl.) 48: 287-307

Tomlinson, P. B. (1974). Vegetative morphology and meristem dependence - the foundation of productivity in seagrasses. Aquaculture 4: 107 -130

Turner, T (1985). Stability of rocky intertidal surfgrass beds; preemption and recovery. Ecology 66: 83-92

Williams, S. L. (1984). Seagrass ecosystems succession: a manipulative experiment. Proc. Assoc. Is. Mar. Labs. Carib. 18: 6

Williams, S. L. (1985). Factors affecting seagrass recolonization. Estuaries 8: 16A

Williams, S. L., McRoy, C. P. (1982). Seagrass productivity: the effect of light on carbon uptake. Aquat. Bot. 12: 321-344

Williams, S. L., Yarish, S. M., Gill, I. P. (1985). Ammonium distributions, production, and efflux from backreef sediments, St. Croix, US Virgin Islands. Mar. Ecol. Prog. Ser. 24: $57-64$

Winfrey, M. R., Zeikus, J. G. (1977). The effect of sulfate on carbon and electron flow during microbial methanogenesis in freshwater sediments. Appl. environ. Microbiol. 33: 275-281

Zieman, J. C. (1976). The ecological effects of physical damage from motor boats on turtle grass beds on southern Florida. Aquat. Bot. 2: 127-139

Zieman, J. C., Iverson, R. L., Ogden, J. C. (1984). Herbivory effects on Thalassia testudinum leaf growth and nitrogen content. Mar. Ecol. Prog. Ser. 15: 151-158

Zieman, J. C., Wetzel, R. G. (1980). Productivity in seagrasses. In: Phillips, R. C., McRoy, C. P. (ed.) A handbook of seagrass biology. Garland Press, New York, p. 87-116

Young, P. C., Kirkman, H. (1975). The seagrass communities of Moreton Bay, Queensland. Aquat. Bot. 1: 191-202

This article was presented by Dr. G. W. Thayer; it was accepted for printing on October 24, 1986 